\title{
Article
}

\section{Anxiety and depression in the age of austerity: public health's problems with IAPT}

Knight, Tamasin and Thomas, Philip

Available at http://clok.uclan.ac.uk/28595/

Knight, Tamasin and Thomas, Philip (2019) Anxiety and depression in the age of austerity: public health's problems with IAPT. Perspectives in Public Health, 139 (3). pp. 128-130. ISSN 1757-9139

It is advisable to refer to the publisher's version if you intend to cite from the work. http://dx.doi.org/10.1177/1757913919839004

For more information about UCLan's research in this area go to http://www.uclan.ac.uk/researchgroups/ and search for <name of research Group>.

For information about Research generally at UCLan please go to http://www.uclan.ac.uk/research/

All outputs in CLoK are protected by Intellectual Property Rights law, including Copyright law. Copyright, IPR and Moral Rights for the works on this site are retained by the individual authors and/or other copyright owners. Terms and conditions for use of this material are defined in the policies page.

\section{CLoK}

Central Lancashire online Knowledge www.clok.uclan.ac.uk

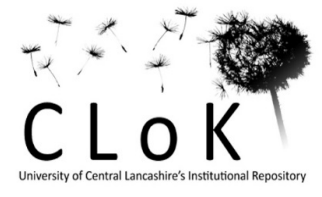


Anxiety and Depression in the Age of Austerity:

Public Health's Problems with IAPT

Philip Thomas ${ }^{1}$

Tamasin Knight ${ }^{2}$

In Press: Perspectives in Public Health Special Issue on

Mental Health

Do not cite without permission

1

Affiliation: Currently none. Formerly Professor of Philosophy, Diversity \& Mental Health, University of Central Lancashire, UK.

2 Consultant in Public Health Medicine

Directorate of Public Health, NHS Tayside, Kings Cross,

Clepington Road, Dundee, DD3 8EA.

Tamasin.Knight@nhs.net 


\section{[15 June 2018: 1020 words ex-refs]}

The English programme Improving Access to Psychological Therapies (IAPT) which began ten years ago originated in the work of an economist, Richard Layard (2004, 2005). It was encouraged and implemented under New Labour, and then enthusiastically continued under the Coalition government (Evans, J., 2013). Layard argued that a population-based service to treat depression and anxiety with evidence-based therapies (originally cognitive therapy - CT) would be revenue-neutral. Reduced government spending on unemployment benefits would offset the expense of setting it up and increased revenue through higher tax receipts as the previously unemployed depressed returned to work. Whether or not this is the case remains an open question.

Enthusiasm for psychological interventions aimed at making the populace happy remains undimmed in current English health policy. The range of interventions has grown to include approaches based in happiness and positive psychology for the public at large, not only those diagnosed with anxiety or depression. For example, Public Health England (PHE) has set out a framework for public mental health leadership and workforce development (DH/PHE, 2015; 2016), which includes links to programmes based in positive psychology and happiness training. Examples given include the "Wheel of Wellbeing" (which aims to train staff in a simple framework to promote 
positive health and wellbeing), a "Do-It-Yourself Happiness game" and DIY happiness training, which explore key concepts from positive psychology (DH/PHE, 2016:15). Another course, Living Life to the Full, (based in the principles of CT) includes sessions on "...how to fix almost anything..." and "..10 things you can do to feel happier straight away..." (ibid:21).

In our view there are serious difficulties with the largescale imposition of psychological interventions on people whose misery and unhappiness primarily originates in socioeconomic adversity. First, the psychological interventions at the heart of IAPT focus primarily on the moral responsibility of the person for the way they feel, and to rectify it (Bracken \& Thomas, 2018; Thomas, 2018). This is because they assume that depression and anxiety arise from faulty attitudes and beliefs that people hold about themselves. Aaron T. Beck, the originator of $\mathrm{CT}$, argued that in depression "...the individual's cognition is distorted and out of step with his or her context..." (Beck, 1972: 7, emphasis added). This involves a value judgement that is difficult to justify. On what basis can we assert that someone is wrong to think negatively and thus to feel hopeless and powerless in the face of overwhelming adversity? Who has the moral authority to make such a judgement, and on what grounds? To declare that someone is depressed because his or her cognitions are faulty and require correction is tantamount to blaming the victim. To 
tell someone that feeling better is simply a matter of having the right set of "positive beliefs" is to shift the responsibility onto the individual, whilst denying the social realities facing people who live precarious existences. Poverty, destitution and its sequelae are seen as individual, not systemic, problems. This “... obscures the causes of inequality, divides communities with shared political interests, corrodes compassion for the poorest in society, and obviates any recognition of the need to challenge disadvantage" (Valentine and Harris, 2014: 87). This malignant individualism (Thomas, 2018) is replacing the ethic of care, concern and compassion that historically have been at the heart of therapy and mental health practice.

Second, although IAPT is aimed at the general population, its targeted use with unemployed and disabled people in JobCentres is deeply worrying. Recent pilot studies of psychological therapies in JobCentres have raised fears that unemployment is being redefined as a psychological problem (Gayle, 2015). These fears are amplified by plans to prioritise IAPT for disabled unemployed people in JobCentres (DWP/DH, 2017) in order to get them back to work, and a commitment from the Royal College of Psychiatrists to use employment as a key clinical outcome for psychiatric treatment. Future priorities for IAPT include supporting people to stay in or find work (Mental Health Taskforce Strategy, 2016). The context here is one in which the 
proportion of benefit spending on people with mental health problems is set to rise. The Institute for Fiscal Studies found that while the total amount spent on disability benefits had fallen from 1999 to 2014, the proportion of claimants with mental health problems increased from 50 to $60 \%$, posing '... an increasingly central issue for future disability policy reform' (Banks, Blundell, \& Emmerson, 2015 , p. 175). It is difficult to avoid the conclusion that the government is indeed turning unemployment into an individual psychological problem to be tackled by psychological interventions.

Third, the discourse of health and mental health inequalities may have (un)intended political consequences. Lynch (2017) argues that reframing the problem of social and income inequality as health inequalities makes it possible for politicians to avoid taking action in politically contentious areas that would redistribute wealth by making the wealthy pay higher taxes, or raising the basic minimum wage and tightening labour market regulations. The same holds for IAPT, which sees anxiety and depression as an individual problem, rather than an inevitable outcome of poverty and destitution related to structural inequalities that require political remedies.

There are practical things that can be done to help those struggling with poverty and destitution, living in despair and without hope. Providing programmes that offer people practical advice about benefits and managing debt is one example. The Deep End Advice Worker Project in Glasgow offers help, advice 
and support in coping with poverty and its related problems (Sinclair, 2017). Rather than changing the way they think about their lives, projects like this offer practical help and advice to enable people improve their economic circumstances which we know is crucial to developing good mental health. Community development offers a variety of ways of working with communities to help them collectively identify and solve the problems they face that affect their health and wellbeing (Gilchrist, 2004). This approach has been used to help innercity communities engage with commissioners and health providers to plan and develop systems of help and support for depression and anxiety that are consistently with the different values and beliefs that characterise multi-cultural communities (Seebohm et al, 2005).

\section{References}

Banks, J., Blundell, R., \& Emmerson, C. (2015). Disability benefit receipt and reform: Reconciling trends in the United Kingdom. Journal of Economic Perspectives, 29, 173-190.

Beck, A.T. (1972) The Diagnosis and Management of Depression, Philadelphia: University of Pennsylvania Press.

Bracken, P. \& Thomas, P. (2018) Cognitive Therapy, Cartesianism and the Moral Order. Chapter 10 in (eds. D. Loewenthal and G. Proctor) Why not CBT? Against and For CBT Revisited. Ross-on-Wye, PCCS Books. Pp. 162 - 178 .

DH/PHE (2015) Public mental health leadership and workforce development framework: Confidence, competence, commitment. PHE, London. Accessed on 7 June 2018 at https://assets.publishing.service.gov.uk/government/uploads/sy 
stem/uploads/attachment_data/file/410356/Public_Mental_Health_ Leadership_and_Workforce_Development_Framework.pdf

DH/PHE (2016) Mental health promotion and prevention training programmes: Emerging practice examples Accessed on 7 June 2018 at

https://assets.publishing.service.gov.uk/government/uploads/sy stem/uploads/attachment_data/file/558676/Mental_health_promoti on_and_prevention_training_programmes.pdf

DWP/DH (2017) Improving Lives: The future of Work, Health and Disability London, Department for Work and Pensions / Department of Health. Accessed on 7 June 2018 at https://assets.publishing.service.gov.uk/government/uploads/sy stem/uploads/attachment_data/file/663399/improving-lives-thefuture-of-work-health-and-disability.PDF

Evans, J. (2013) Richard Layard on happiness, CBT and Christianity The History of Emotions Blog, accessed on 7 June 2018 at https: / /emotionsblog.history.qmul.ac.uk/2013/04/richardlayard-on-happiness-cbt-and-christianity/

Gayle, D. (2015) Mental health workers protest at move to integrate clinic with jobcentre The Guardian, Fri 26 July Accessed at

https : / /www. theguardian.com/society/2015/jun/26/mental-healthprotest-clinic-jobcentre-streatham on 6 June 2018

Gilchrist, A. (2004) The Well-Connected Community: A networking approach to community development. Bristol: The Policy Press.

Layard, R. (2004). Mental health: Britain's biggest social problem. London: Department of Health. Accessed at http://eprints.1se.ac.uk/47428/ on 7 June 2018

Layard, R. (2005) Happiness: Lessons from a New Science. New York and London, Penguin.

Layard, R. (2006) The case for psychological treatment centres British Medical Journal 332:1030-2

Mental Health Taskforce Strategy (2016) The Five Year Forward View for Mental Health Mental Health Taskforce to the NHS in England accessed on 7 June 2018 at https : / /www. england.nhs.uk/wp-content/uploads/2016/02/MentalHealth-Taskforce-FYFV-final.pdf (see p. 15)

Royal College of Psychiatrists (2017) Work is a key clinical outcome Accessed at https : / /www.rcpsych.ac.uk/usefulresources/workandmentalhealth/ 
clinician/workisakeyclinicaloutcome.aspx on 7 June 2018

Seebohm, P., Henderson, P., Munn-Giddings, C., Thomas, P. \& Yasmeen, S. (2005) Together We Will Change: Community development, mental health and diversity. London: Sainsbury Centre for Mental Health.

Sinclair, J. (2017) The Deep End Advice Worker Project: embedding an advice worker in general practice settings. Glasgow Centre for Population Health September 2017, accessed on 7 June 2018 at

http://wWw.gcph.co.uk/assets/0000/6242/Deep_End_FINAL_WEB.pdf

Thomas. P. (2018) Neoliberalism: What is it, and why does it matter? Chapter 1 in (eds. R. Rizq and C. Jackson) The Industrialisation of Care: Counselling and Psychotherapy in a Neoliberal Age. Ross-on-Wye, PCCS Books, forthcoming.

Valentine, G. \& Harris, C. (2014) Strivers vs skivers: Class prejudice and the demonisation of dependency in everyday life. Geoforum 53, 84-92

http://dx.doi.org/10.1016/j.geoforum.2014.02.007 